\title{
Phase I dose-escalation study of aflibercept in combination with docetaxel and cisplatin in patients with advanced solid tumours
}

\author{
G Freyer,', N Isambert ${ }^{2,3}$, B You', S Zanetta ${ }^{2,3}$, C Falandry', L Favier', V Trillet-Lenoir', S Assadourian ${ }^{4}$, \\ K Soussan-Lazard ${ }^{4}$, S Ziti-Ljajic ${ }^{5}$ and P Fumoleau ${ }^{2,3}$
}

'Université de Lyon, Service d'oncologie médicale, Centre d'Investigation des Thérapeutiques en Oncologie et Hématologie, Centre Hospitalier Lyon-Sud, Pierre Benite 69495, France; ${ }^{2}$ Centre Georges François Leclerc, Dijon 21079 , France; ${ }^{3}$ Centre d'Investigation Clinique Plurithématique 803 (INSERM CIC-P 803), Dijon 21079, France; ${ }^{4}$ Sanofi-aventis Oncology, Vitry-sur-Seine, France; ${ }^{5}$ Sanofi-aventis PK unit, Alfortville 94 I 40, France

BACKGROUND: This phase I cohort study investigated aflibercept (vascular endothelial growth factor (VEGF) trap) plus docetaxel and cisplatin in patients with advanced solid tumours.

METHODS: Patients received intravenous aflibercept 4,5 , or $6 \mathrm{mg} \mathrm{kg}^{-1}$ with docetaxel and cisplatin (75 $\mathrm{mg} \mathrm{m}^{-2}$ each) on day I of a 3-week cycle until progressive disease or unacceptable toxicity. Primary objectives were determining cycle I dose-limiting toxicities (DLTs) and the aflibercept recommended phase II trial dose (RP2D) for this combination.

RESULTS: During the dose-escalation phase $(n=16)$, there were two DLTs of febrile neutropenia (at 4 and $5 \mathrm{mg} \mathrm{kg}{ }^{-1}$ ). Granulocyte colony-stimulating factor prophylaxis was subsequently recommended. The RP2D of aflibercept was established at $6 \mathrm{mg} \mathrm{kg}^{-1}$ and administered to 14 additional patients. The most frequent grade $3 / 4$ adverse events (AEs) were neutropenia (43.3\%), stomatitis (20.0\%), asthenia/fatigue (20.0\%), and hypertension (16.7\%). All-grade AEs associated with VEGF blockade included epistaxis (83.3\%), dysphonia (70.0\%), proteinuria (53.3\%), and hypertension (50.0\%). There were five partial responses (I6.7\%) and I8 cases of stable disease (60.0\%) (lasting $>3$ months in 10 patients). There were no pharmacokinetic (PK) interactions between the three drugs. CONCLUSION: Aflibercept $6 \mathrm{mg} \mathrm{kg}^{-1}$ with docetaxel and cisplatin $75 \mathrm{mg} \mathrm{m}^{-2}$ every 3 weeks is the RP2D based on tolerability, antitumour activity, and PKs.

British Journal of Cancer (2012) 1 07, 598-603. doi:I0.1038/bjc.2012.304 www.bjcancer.com

Published online 12 July 2012

(C) 2012 Cancer Research UK

Keywords: aflibercept; VEGF trap; angiogenesis; anti-VEGF therapy

Vascular endothelial growth factor (VEGF) has a key role in tumour angiogenesis by stimulating endothelial cell growth, migration and survival, and increasing vessel permeability (Ferrara, 2002; Hicklin and Ellis, 2005). Targeting VEGF with bevacizumab (a recombinant humanised anti-human VEGF monoclonal antibody), plus chemotherapy, has resulted in improved outcomes in patients with metastatic colorectal, lung, and breast cancers (Hurwitz et al, 2004; Sandler et al, 2006; Miles et al, 2010). As the antitumour activity of anti-VEGF therapy has been demonstrated, opportunities exist to further optimise these therapies to deliver further efficacy improvements.

Aflibercept (VEGF Trap) is a recombinant fusion protein consisting of VEGF-binding portions from the extracellular domains of human VEGF receptors 1 and 2 fused to the Fc portion of human IgG1 (Holash et al, 2002). Aflibercept has broad affinity for all ligands that bind to these receptors, including isoforms of VEGF-A, VEGF-B, and placental growth factors (Holash et al, 2002; Verheul et al, 2007). In preclinical models, aflibercept demonstrated antitumour effects and antiangiogenic activity as a single agent and enhanced activity in combination with chemotherapy, including cisplatin, taxanes, and gemcitabine (Holash et al, 2002; Byrne et al, 2003; Huang et al, 2003; Fukasawa

*Correspondence: Dr G Freyer; E-mail: Gilles.Freyer@chu-lyon.fr Received 20 February 20 I2; revised 18 June 2012; accepted 18 June 20 I2; published online 12 July 2012 and Korc, 2004; Verheul et al, 2007; Leujeune et al, 2008; Lal et al, 2010; Lassoued et al, 2011).

A phase I study demonstrated the safety and activity of singleagent aflibercept in patients with haematologic malignancies or solid tumours (Lockhart et al, 2010). In a phase I, dose-escalation, sequential cohort study in patients with advanced solid tumours (Isambert et al, 2011), aflibercept $6 \mathrm{mg} \mathrm{kg}^{-1}$ with docetaxel $75 \mathrm{mg} \mathrm{m}^{-2}$ every 3 weeks was established as the recommended phase II trial dose (RP2D). In the second cohort from this study, reported here, the safety and tolerability of aflibercept plus platinum-based doublet chemotherapy, specifically docetaxel and cisplatin, was investigated.

\section{MATERIALS AND METHODS}

\section{Eligibility}

Patients aged $\geqslant 18$ years were included if they had a histologically or cytologically confirmed solid malignancy that was metastatic or unresectable or for which no standard conventional curative therapy existed, but for which treatment with the combination of docetaxel plus cisplatin was considered appropriate. Other main inclusion criteria were Eastern Cooperative Oncology Group performance status $\leqslant 2$, adequate haematologic, hepatic and renal function, and resolution of any toxicity (except alopecia) from other anticancer treatments. Key exclusion criteria were squamous 
cell lung carcinoma; brain metastases; cumulative radiotherapy to $>25 \%$ of the total bone marrow; chemotherapy, hormonal therapy, radiotherapy or surgery during the previous 3 weeks; immunotherapy or cytokine therapy within the previous 6 weeks; or uncontrolled hypertension. All patients gave written informed consent. The study (EudraCT number: 2005-001984-77) was approved by the local ethics committees and conducted according to the Declaration of Helsinki.

\section{Study design and treatment}

This was a two centre, phase I, dose-escalation, sequential cohort study. In the dose-escalation phase of the cohort reported here, patients received aflibercept (sanofi-aventis and Regeneron Pharmaceuticals Inc., 2011) by intravenous (IV) infusion over $1 \mathrm{~h}$ on day 1 at a starting dose of $4 \mathrm{mg} \mathrm{kg}^{-1}$, with enrolment into the next dose levels (5 and $6 \mathrm{mg} \mathrm{kg}^{-1}$ ) based on dose-limiting toxicity (DLT) observations during the first cycle (i.e., 3-week period). Dose-escalation to the subsequent dose level was made if no DLT was seen in a cohort of three patients. If DLT was observed in one patient, the cohort was expanded by at least three patients. Once the RP2D had been determined, additional patients were enrolled in an expansion cohort to further evaluate the safety and activity of the combination at the RP2D.

After the aflibercept IV infusion, all patients immediately received docetaxel $75 \mathrm{mg} \mathrm{m}^{-2}$ by IV infusion over $1 \mathrm{~h}$ then an IV infusion of cisplatin $75 \mathrm{mg} \mathrm{m}^{-2}$ over $1 \mathrm{~h}$. Prophylactic use of hematopoietic growth factors was not initially permitted in the first cycle. Cycles were repeated every 3 weeks until Response Evaluation Criteria in Solid Tumours (RECIST version 1.0)-defined progressive disease (Therasse et al, 2000), unacceptable toxicity, or withdrawal of patient's consent.

\section{Study objectives}

Primary objectives were to evaluate DLTs during the first cycle and determine the RP2D of aflibercept in combination with docetaxel and cisplatin. Secondary objectives were to assess safety, preliminary antitumour activity, pharmacokinetics (PKs), and immunogenicity during the entire study period.

\section{Safety and efficacy assessments}

Safety was assessed based on adverse events (AEs) (collected until 60 days after the end of study treatment), laboratory data, electrocardiograms, physical examinations, and the presence of aflibercept antibodies. Toxicities were graded using the National Cancer Institute Common Terminology Criteria for Adverse Events (version 3.0). Haematologic DLTs were grade 3/4 neutropenia complicated by fever $\geqslant 38.5^{\circ} \mathrm{C}$ or infection, grade 4 neutropenia for $\geqslant 7$ days, grade 4 thrombocytopenia, or grade 3 thrombocytopenia with haemorrhage. Nonhaematologic DLTs were grade 3/4 nonhaematologic toxicities except fatigue, anorexia, nausea, vomiting, diarrhoea, serum alkaline phosphatase increase, or grade 3 events that were considered by the investigator and sponsor to be not clinically relevant or unrelated to study treatment. Nonhaematologic DLTs also included blood pressure $\geqslant 150 / 100 \mathrm{~mm} \mathrm{Hg}$ (or $\geqslant 180 / 90 \mathrm{~mm} \mathrm{Hg}$ in patients with prior history of systolic hypertension) despite 4 weeks' medical management; urine protein $>3.5 \mathrm{~g}$ per $24 \mathrm{~h}$ that did not recover to $<2.0 \mathrm{~g}$ per $24 \mathrm{~h}$ within 2 weeks; and symptomatic arterial thromboembolic events. Safety evaluations were performed on all patients exposed to at least one dose of aflibercept (safetyevaluable population).

Tumour response was assessed according to RECIST criteria version 1.0 using magnetic resonance imaging (MRI) or computed tomography (CT) on day 21 ( \pm 4 days) of every even-numbered cycle, at the end of the study treatment, if disease progression was suspected or to confirm a response. Patients evaluable for antitumour activity were those who underwent baseline assessment, received at least two cycles of study treatment, and had at least one post-baseline CT or MRI scan unless early progression or death occurred.

\section{Pharmacokinetic assessments and analysis}

Pharmacokinetic analyses were performed on the safety-evaluable population. Plasma samples were obtained pretreatment, then at $1,2,4,8,24$, and $48 \mathrm{~h}$ after the start of aflibercept infusion on days 1,7 , and 14 during cycle 1 . Samples were collected before dosing for subsequent cycles and at the end of treatment. Levels of free aflibercept and VEGF:aflibercept complex (VEGF-bound aflibercept) were measured in plasma by direct enzyme-linked immunosorbantbased assay (ELISA), with a limit of quantification (LOQ) of 15.6 and $43.9 \mathrm{ng} \mathrm{ml}^{-1}$, respectively. Concentrations of VEGF-bound aflibercept were converted into equivalents of free aflibercept taking into account molecular weights before PK analysis. Pharmacokinetic parameters of free and VEGF-bound aflibercept were assessed using non-compartmental analysis (WinNonlin Professional, version 5.2.1, PharSight, Raleigh-Durham, NC, USA). Pharmacokinetic parameters for both free and VEGF-bound aflibercept were plasma concentrations before starting infusion at each treatment cycle $\left(C_{\text {trough }}\right)$ and the maximum observed plasma concentration $\left(C_{\max }\right)$. For VEGF-bound aflibercept only, time to reach $C_{\max }\left(t_{\max }\right)$ and area under the concentration $v s$ time curve from time 0 to $t_{\text {last }}$ (time corresponding to the last plasma concentration above the LOQ) $\left(\mathrm{AUC}_{\text {last }}\right)$ were measured. Additional parameters for free aflibercept only included AUC from time 0 to infinity $\left(\mathrm{AUC}_{0-\infty}\right)$, terminal elimination half-life $\left(t_{1 / 2}\right)$, and clearance $(\mathrm{CL})$.

Plasma samples for docetaxel and total cisplatin analysis were obtained pretreatment and at various time points on cycle 1, day 1; plasma levels were measured by electrospray liquid chromatography mass spectrometry (LOQ $1.00 \mathrm{ng} \mathrm{ml}^{-1}$ ) and by inductively coupled plasma mass spectrometry (LOQ $100 \mathrm{ng} \mathrm{ml}^{-1}$ ). Pharmacokinetic parameters were estimated using a Bayesian estimation method for docetaxel (CL) and by non-compartmental analysis for cisplatin $\left(\mathrm{AUC}_{0-24}\right)$.

\section{Immunogenicity}

Serum samples were obtained from all treated patients, before aflibercept dosing on day 1 of each odd-numbered treatment cycle, at the end of treatment, and 3 months after the last aflibercept administration. Detection of anti-aflibercept antibodies was performed using a validated quasi-quantitative ELISA method.

\section{RESULTS}

Between 20 March 2006 and 1 February 2008, 30 patients were enrolled and treated, 16 in the dose-escalation phase and 14 in the expansion cohort (Table 1). The median age was 53.5 (range, 27-76) years and most patients had advanced breast $(23.3 \%)$ or ovarian cancer (20.0\%). Twenty-nine patients (96.7\%) had received prior chemotherapy. Fifteen had received taxanes and three of these were considered taxane refractory (i.e., had progressive disease as the best overall response: one receiving $4 \mathrm{mg} \mathrm{kg}^{-1}$ and two receiving $6 \mathrm{mg} \mathrm{kg}^{-1}$ ). Ten patients had received cisplatin or carboplatin, two of whom were refractory. All patients discontinued the study treatment for the following reasons: RECIST-defined progressive disease (11 patients), clinical progressive disease (symptoms increase and general heath deterioration considered by the investigator as due to progressive disease in 5 patients) and biological progression (raised tumour marker levels in 1 patient), AEs (11 patients), and planned cancer surgery ( 2 patients). 
Table I Patient and tumour characteristics at baseline

\begin{tabular}{|c|c|c|c|c|}
\hline & $\begin{array}{l}\text { Aflibercept, } \\
\begin{array}{l}\mathbf{4} \mathrm{mg} \mathrm{kg}^{-1} \\
n=6\end{array}\end{array}$ & $\begin{array}{l}\text { Aflibercept, } \\
\mathbf{5} \mathbf{~ m g ~ k g ~}^{-1} \\
\mathbf{n = 7}\end{array}$ & $\begin{array}{l}\text { Aflibercept, } \\
\begin{array}{c}6 \mathrm{mg} \mathrm{kg}^{-1} \\
n=17\end{array}\end{array}$ & $\begin{array}{l}\text { Aflibercept, } \\
\text { all, } n=30\end{array}$ \\
\hline $\begin{array}{l}\text { Gender, female, } \\
n(\%)\end{array}$ & $6(100.0)$ & $7(100.0)$ & $8(47.1)$ & $21(70.0)$ \\
\hline $\begin{array}{l}\text { Median age, } \\
\text { years (range) }\end{array}$ & $52.5(45-69)$ & $53.0(39-58)$ & $57.0(27-76)$ & $53.5(27-76)$ \\
\hline \multicolumn{5}{|c|}{ ECOG performance status, n (\%) } \\
\hline 0 & $2(33.3)$ & $7(100.0)$ & $7(43.8)$ & $16(55.2)$ \\
\hline । & $4(66.7)$ & 0 & $9(56.3)$ & $13(44.8)$ \\
\hline \multicolumn{5}{|c|}{ Primary tumour site, n (\%) } \\
\hline Breast & $3(50.0)$ & $2(28.6)$ & $2(11.8)$ & $7(23.3)$ \\
\hline Ovary & $3(50.0)$ & $2(28.6)$ & $(5.9)$ & $6(20.0)$ \\
\hline Colon & 0 & I (14.3) & $3(17.6)$ & $4(13.3)$ \\
\hline Sarcoma & 0 & 0 & $4(23.5)$ & $4(13.3)$ \\
\hline Rectum & 0 & 0 & $2(11.8)$ & $2(6.7)$ \\
\hline Other ${ }^{\mathrm{a}}$ & 0 & $2(28.6)$ & $5(29.4)$ & $7(23.3)$ \\
\hline $\begin{array}{l}\text { Median number } \\
\text { of organs } \\
\text { involved (range) }\end{array}$ & $2.5(1-4)$ & $2.0(1-6)$ & $2.0(1-5)$ & $2.0(1-6)$ \\
\hline $\begin{array}{l}\text { Prior surgery, } \\
n(\%)\end{array}$ & $6(100.0)$ & $7(100.0)$ & $14(82.4)$ & $27(90.0)$ \\
\hline $\begin{array}{l}\text { Prior } \\
\text { radiotherapy, } \\
n(\%)\end{array}$ & $3(50.0)$ & $3(42.9)$ & $6(35.3)$ & $12(40.0)$ \\
\hline $\begin{array}{l}\text { Prior } \\
\text { chemotherapy, } \\
\mathrm{n}(\%)\end{array}$ & $6(100.0)$ & $7(100.0)$ & $16(94.1)$ & $29(96.7)$ \\
\hline $\begin{array}{l}\text { Median number } \\
\text { of lines of prior } \\
\text { chemotherapy } \\
\text { (range) }\end{array}$ & $4.0(3-4)$ & $4.0(2-4)$ & $2.5(1-5)$ & $4.0(1-5)$ \\
\hline $\begin{array}{l}\text { Prior taxane } \\
\text { therapy, } n(\%)\end{array}$ & $6(100.0)$ & $4(57.1)$ & $5(29.4)$ & $15(50.0)$ \\
\hline $\begin{array}{l}\text { Prior platinum } \\
\text { therapy }, n(\%)\end{array}$ & $4(66.6)$ & $4(57.1)$ & $2(11.8)$ & $10(33.3)$ \\
\hline
\end{tabular}

Abbreviation: ECOG, Eastern Cooperative Oncology Group. alncluding cancers of the cervix, oesophagus, eye, lung, other female genital organs, pancreas, and pleura. ${ }^{\mathrm{b}}$ Cisplatin or carboplatin.

\section{Study drug exposure}

Thirty patients received a total of 171 infusions of aflibercept, with a median of 5 (range, 1-13) infusions. The median relative dose intensity (RDI) for aflibercept was 0.91 with $4 \mathrm{mg} \mathrm{kg}^{-1}, 0.92$ with $5 \mathrm{mg} \mathrm{kg}^{-1}$, and 1.00 with $6 \mathrm{mg} \mathrm{kg}^{-1}$ (Table 2). Median RDIs for docetaxel $(0.83)$ and cisplatin $(0.75)$ were lower than those for aflibercept due to high numbers of dose reductions $(36.7 \%$ and $46.7 \%$ of patients, respectively) and the premature discontinuation of chemotherapy secondary to chemotherapy-related toxicity ( $30.0 \%$ and $50.0 \%$ of patients, respectively).

\section{Safety evaluation}

At the first aflibercept dose level of $4 \mathrm{mg} \mathrm{kg}^{-1}$, one patient out of three experienced febrile neutropenia, considered as a DLT. Three additional patients were enrolled at this dose level, with no DLTs observed. In the aflibercept $5 \mathrm{mg} \mathrm{kg}^{-1}$ cohort, one of the first two patients receiving aflibercept experienced febrile neutropenia. The protocol was subsequently amended to recommend primary prophylaxis with granulocyte colony-stimulating factor (G-CSF) starting in cycle 1 . It was decided not to consider febrile neutropenia as a DLT, as it was mainly due to chemotherapy and could be effectively prevented by G-CSF administration. The third patient treated at $5 \mathrm{mg} \mathrm{kg}^{-1}$ received prophylactic G-CSF
Table 2 Median exposure, actual dose intensity, and relative dose intensity by dose level

\begin{tabular}{|c|c|c|c|}
\hline & $\begin{array}{l}\text { Aflibercept, } \\
\begin{array}{l}\mathbf{4} \mathbf{~ m g ~ k g ~}^{-1} \\
n=6\end{array}\end{array}$ & $\begin{array}{c}\text { Aflibercept, } \\
\begin{array}{c}5 \mathbf{~ m g ~ k g ~}^{-1} \\
n=7\end{array}\end{array}$ & $\begin{array}{c}\text { Aflibercept, } \\
\begin{array}{c}6 \mathbf{~ m g ~ k g}^{-1} \\
n=17\end{array}\end{array}$ \\
\hline $\begin{array}{l}\text { Median number of aflibercept } \\
\text { infusions (range) }\end{array}$ & $5(3-8)$ & $6(3-12)$ & $4(1-13)$ \\
\hline \multicolumn{4}{|c|}{ Aflibercept dose intensity (mg kg-1 per week) } \\
\hline Median (range) & $1.21(1.0-1.3)$ & $1.54(1.4-1.7)$ & $1.99(1.4-2.0)$ \\
\hline \multicolumn{4}{|c|}{ Aflibercept relative dose intensity } \\
\hline Median (range) & $0.91(0.8-1.0)$ & $0.92(0.8-1.0)$ & $1.00(0.7-1.0)$ \\
\hline $\begin{array}{l}\text { Median number of docetaxel } \\
\text { infusions (range) }\end{array}$ & $4.5(3-6)$ & $6(3-12)$ & $4(1-9)$ \\
\hline \multicolumn{4}{|l|}{ Docetaxel relative dose intensity } \\
\hline Median (range) & $0.81(0.5-1.0)$ & $0.81(0.6-1.0)$ & $0.85(0.4-1.0)$ \\
\hline $\begin{array}{l}\text { Median number of cisplatin } \\
\text { infusions (range) }\end{array}$ & $4.5(2-6)$ & $6(3-9)$ & $4(1-8)$ \\
\hline \multicolumn{4}{|l|}{ Cisplatin relative dose intensity } \\
\hline Median (range) & $0.70(0.5-1.0)$ & $0.83(0.5-1.0)$ & $0.77(0.4-1.0)$ \\
\hline
\end{tabular}

and, subsequently, four additional patients received $5 \mathrm{mg} \mathrm{kg}^{-1}$, without experiencing DLT. Three patients received aflibercept $6 \mathrm{mg} \mathrm{kg}^{-1}$, without experiencing DLTs. In another phase I study, combining aflibercept with docetaxel $75 \mathrm{mg} \mathrm{m}^{-2}$, the RP2D of aflibercept was established at $6 \mathrm{mg} \mathrm{kg}^{-1}$ (Isambert et al, 2011). As the addition of cisplatin did not appear to impact on tolerability, aflibercept $6 \mathrm{mg} \mathrm{kg}^{-1}$ in combination with docetaxel $75 \mathrm{mg} \mathrm{m}^{-2}$ and cisplatin $75 \mathrm{mg} \mathrm{m}^{-2}$ was selected as the RP2D for the triplet combination and aflibercept dose-escalation was halted, although no DLTs were observed after the amendment Fourteen additional patients received aflibercept $6 \mathrm{mg} \mathrm{kg}^{-1}$ plus docetaxel and cisplatin in an expansion cohort, five of whom had DLTs: three had stomatitis, one had back pain, and one reported chest pain.

All 30 patients experienced at least one treatment-associated AE on study treatment. The 10 most common nonhaematologic AEs (all grades and across all dose groups) regardless of relationship to study medication were: asthenia/fatigue (100.0\%), epistaxis $(83.3 \%)$, stomatitis $(76.7 \%)$, nausea $(73.3 \%)$, dysphonia, $(70.0 \%)$, diarrhoea $(60.0 \%)$, vomiting $(60.0 \%)$, headache $(56.6 \%)$, hypertension $(50.0 \%)$, and alopecia $(40.0 \%)$. Treatment-emergent AEs are presented in Table 3 . The most frequent grade $3 / 4$ nonhaematologic AEs were asthenia/fatigue and stomatitis (six patients each, $20.0 \%$ each), hypertension (five patients, 16.7\%) and musculoskeletal, and connective tissue pains (three patients, 10.0\%). Most patients experienced haematologic toxicity, with no apparent dose effect (Table 3).

Adverse events (all grades) associated with VEGF blockade were observed at all dose levels and included epistaxis (83.3\%), dysphonia $(70.0 \%)$, proteinuria $(53.3 \%)$, and hypertension $(50.0 \%)$. High blood pressure occurred predominantly in cycles 1 or 2 and was well controlled with antihypertensive medication (mainly calcium channel blockers and diuretics). Sixteen patients experienced proteinuria, with grade 3 proteinuria and thrombotic microangiopathy reported in one patient receiving $6 \mathrm{mg} \mathrm{kg}^{-1}$. One patient in the $4 \mathrm{mg} \mathrm{kg}^{-1}$ group experienced grade $3 / 4$ pulmonary embolism and one patient in the $6 \mathrm{mg} \mathrm{kg}^{-1}$ group experienced grade $3 / 4$ deep-vein thrombosis. Grade 3/4 intestinal perforation was reported in one patient who received aflibercept $5 \mathrm{mg} \mathrm{kg}^{-1}$ : treatment was discontinued, surgery was performed, and the patient's general condition improved rapidly.

The main haematologic AEs were lymphopenia and anaemia $(90.0 \%$ each). Grade $3 / 4$ neutropenia was reported in all patients who received aflibercept $4 \mathrm{mg} \mathrm{kg}^{-1}$ (who did not receive 
Phase I cohort study of aflibercept, docetaxel, and cisplatin

Table 3 Relevant nonhaematologic and haematologic treatment-emergent adverse events occurring with an incidence of $10 \%$ or more

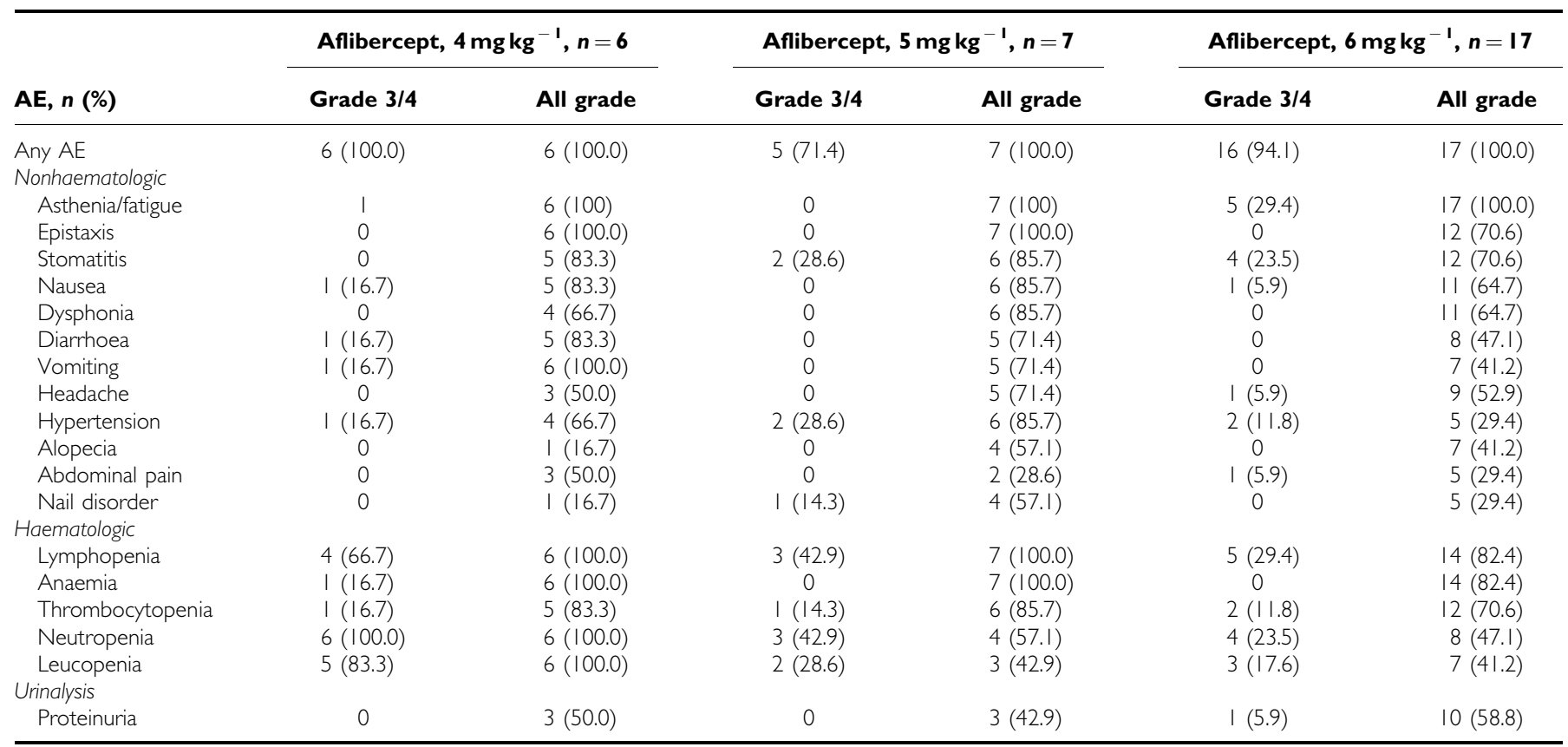

Abbreviation: $A E=$ adverse event.

prophylactic G-CSF), but in only $23.5 \%$ of patients treated at the RP2D (under prophylactic G-CSF).

Eighteen patients died of malignant disease, with no deaths due to treatment-related toxicity. Adverse events leading to study treatment withdrawal were experienced by four patients in the $4 \mathrm{mg} \mathrm{kg}^{-1}$ group (paraesthesia, cardiomyopathy secondary to pulmonary embolism, organising pneumonia, and peritonitis and general physical health deterioration secondary to subileus (no perforation found)), by two in the $5 \mathrm{mg} \mathrm{kg}^{-1}$ group (docetaxel hypersensitivity and intestinal perforation) and by five in the $6 \mathrm{mg} \mathrm{kg}^{-1}$ group (aflibercept hypersensitivity, device-related infection, proteinuria, cytolytic hepatitis, and grand mal convulsion). Twenty-one patients had at least one dose reduction of study treatment (among these, three patients had aflibercept dose reduction) due to AEs, commonly due to nail disorder (five patients) and stomatitis (four patients). Adverse events were similar for the three dose level groups, except that more fatigue/asthenia, musculoskeletal, and connective tissue pains but less hypertension and epistaxis were observed at the RP2D $6 \mathrm{mg} \mathrm{kg}^{-1}$ dose level. No conclusion can be drawn from these findings because of the small sample size of patients per dose level. Generally there was no pattern of AEs related to aflibercept dose.

\section{Antitumour activity}

In one patient, the tumour was not evaluable due to a lack of proper assessment during the study. Five patients had a partial response (PR): one at $4 \mathrm{mg} \mathrm{kg}^{-1}$ and four at $6 \mathrm{mg} \mathrm{kg}^{-1}$ (Table 4). Partial responses occurred in two patients with ovarian cancer (at 4 and $6 \mathrm{mg} \mathrm{kg}^{-1}$ ) and one patient each with cancer of the breast, oesophagus, and pancreas (all receiving $6 \mathrm{mg} \mathrm{kg}^{-1}$ ). The patients with breast or ovarian cancer were all pretreated and refractory to taxanes. All six patients with ovarian cancer were pretreated with platinum agents. The longest duration of response was 19.1 months in a breast cancer patient with four prior lines of chemotherapy who received 12 cycles of study treatment. Eighteen patients had stable disease (SD). Ten of these patients had SD lasting $>3$ months, two of whom had SD lasting $>10$ months.
Table 4 Antitumour activity

\begin{tabular}{|c|c|c|c|c|}
\hline & $\begin{array}{l}\text { Aflibercept, } \\
\begin{array}{l}\mathbf{4} \mathbf{~ m g ~ k g ~}^{-1} \\
n=6\end{array}\end{array}$ & $\begin{array}{l}\text { Aflibercept, } \\
\begin{array}{l}5 \mathbf{~ m g ~ k g ~}^{-1} \\
n=7\end{array}\end{array}$ & $\begin{array}{c}\text { Aflibercept, } \\
6 \mathbf{~ m g ~ k g ~}^{-1} \\
n=17\end{array}$ & $\begin{array}{c}\text { All } \\
\text { patients, } \\
n=30\end{array}$ \\
\hline \multicolumn{5}{|c|}{ Best overall response, n (\%) } \\
\hline Partial response & ( 16.7$)$ & 0 & $4(23.5)$ & $5(16.7)$ \\
\hline Stable disease & $4(66.7)$ & $7(100.0)$ & $7(41.2)$ & $18(60.0)$ \\
\hline Progressive disease & 0 & 0 & $6(35.3)$ & $6(20.0)$ \\
\hline Not evaluable & I (16.7) & 0 & 0 & I (3.3) \\
\hline $\begin{array}{l}\text { Patients with stable } \\
\text { disease for }>3 \\
\text { months, } n(\%)\end{array}$ & $3(50.0)$ & $3(42.9)$ & $4(23.5)$ & $10(33.3)$ \\
\hline
\end{tabular}

\section{Pharmacokinetic evaluation}

Plasma concentration-time profiles for free and VEGF-bound aflibercept over cycle 1 are shown in Figure 1. The PK parameters for free and VEGF-bound aflibercept at cycle 1 are summarised in Table 5. Mean exposures to free aflibercept were similar across the dose range tested with a 1.2 -fold $(90 \%$ confidence interval (CI), $0.91-1.5$ ) and 0.99 -fold (90\% CI, 0.78-1.3) increase in $C_{\max }$ and AUC, respectively, for a 1.5 -fold increase in dose. However, individual free aflibercept CL values were consistent with observations obtained in the first cohort (Isambert et al, 2011), supporting linearity of PK in the $4-6 \mathrm{mg} \mathrm{kg}^{-1}$ dose range. Terminal half-life was around 5 days. Across the same dose range, exposures to VEGFbound aflibercept were constant, with a 1.1 -fold (90\% CI, $0.80-1.4)$ and 1.1-fold (90\% CI, 0.89-1.3) increase in $C_{\max }$ and $\mathrm{AUC}_{\text {last }}$, respectively, for a 1.5 -fold increase in dose. At 4,5 , or $6 \mathrm{mg} \mathrm{kg}^{-1}$, VEGF-bound aflibercept reached a plateau by cycle 3 . Under steadystate conditions, the mean free to VEGF-bound aflibercept $C_{\text {trough }}$ ratio was higher than 1 at all doses studied (Table 6). The doublet combination of docetaxel and cisplatin did not have an impact on the PK profile of aflibercept (Lockhart et al, 2010). 


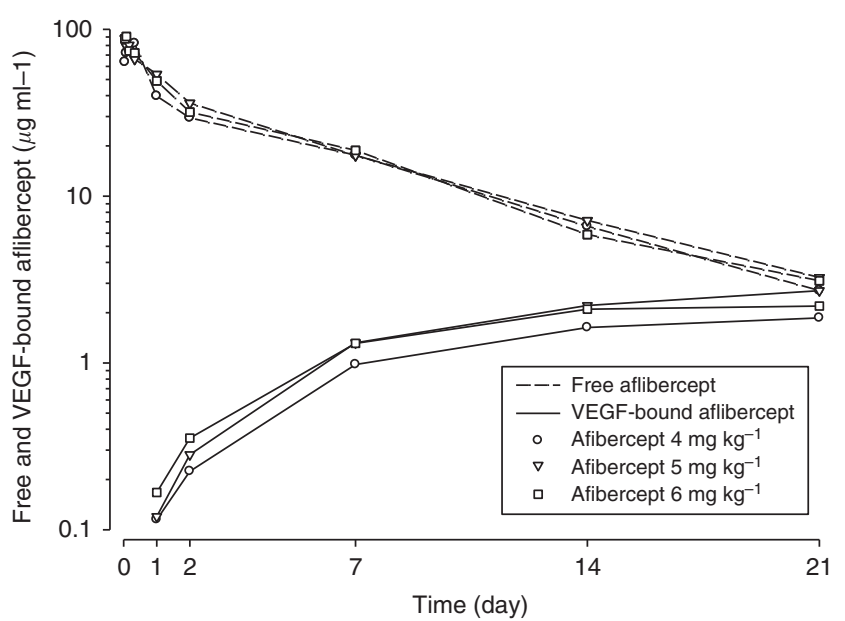

Figure I Mean free and VEGF-bound aflibercept concentration over time profiles at cycle I. Abbreviation: VEGF = vascular endothelial growth factor.

Table 5 Mean (CV \%) free and VEGF-bound aflibercept pharmacokinetic parameters at cycle I

\begin{tabular}{|c|c|c|c|}
\hline & $\begin{array}{l}\text { Aflibercept, } \\
4 \mathrm{mg} \mathrm{kg}^{-1}\end{array}$ & $\begin{array}{l}\text { Aflibercept, } \\
5 \mathrm{mg} \mathrm{kg}^{-1}\end{array}$ & $\begin{array}{l}\text { Aflibercept, } \\
6 \mathrm{mg} \mathrm{kg}^{-1}\end{array}$ \\
\hline \multicolumn{4}{|l|}{ Free aflibercept } \\
\hline Number of patients & 6 & 7 & 16 \\
\hline$C_{\max }, \mu \mathrm{g} \mathrm{ml}^{-1}$ & $93.5(49)$ & $96.4(20)$ & $106(38)$ \\
\hline $\begin{array}{l}\mathrm{A} \cup \mathrm{C}_{0-\infty} \\
\mu \mathrm{g} \text { day ml }\end{array}$ & $369(35)$ & $397(20)$ & $372(32)$ \\
\hline$t_{1 / 2}$, day & $5.46(36)$ & $5.60(26)$ & $4.76(28)$ \\
\hline $\mathrm{CL}$, I per day & $0.624(22)$ & $0.797(16)$ & $1.22(32)$ \\
\hline \multicolumn{4}{|l|}{ VEGF-bound aflibercept } \\
\hline Number of patients & 6 & 7 & 17 \\
\hline$C_{\max }, \mu \mathrm{g} \mathrm{ml}^{-1}$ & $1.92(19)$ & $2.67(28)$ & $2.30(42)$ \\
\hline$t_{\max }$, day & $17.5(\mid 3.8-21.1)$ & $21.2(14.0-22.9)$ & $21.0(7.0-21.3)$ \\
\hline$t_{\text {last, }}$ day & $21.0(19.9-21.1)$ & $21.2(21.0-22.9)^{\mathrm{b}}$ & $21.1(20.1-21.3)^{c}$ \\
\hline $\begin{array}{l}\mathrm{A} \cup \mathrm{C}_{\text {last, }} \\
\mu \mathrm{g} \text { day ml }\end{array}$ & $24.4(13)$ & $35.3(38)^{\mathrm{b}}$ & $27.9(18)^{c}$ \\
\hline
\end{tabular}

Abbreviations: $\mathrm{AUC}_{0-\infty}=$ area under the concentration vs time curve from time 0 to infinity $(\infty)$; $A \cup C_{\text {last }}=$ area under the concentration vs time curve from time 0 to $t_{\text {last }} ; C_{\max }=$ maximum observed plasma concentration; $C L=$ clearance; $\mathrm{CV}=$ coefficient of variation; $t_{1 / 2}=$ terminal elimination half-life; $t_{\text {last }}=$ time corresponding to the last plasma concentration above the limit of quantification; $t_{\max }=$ time of maximum plasma concentration; $\mathrm{VEGF}=$ vascular endothelial growth factor. ${ }^{\text {M Median }}$ (minimum - maximum) values. ${ }^{b} n=6 .{ }^{c} n=13$.

Table 6 Mean (CV \%) of steady-state aflibercept individual median $C_{\text {trough value }}$

$C_{\text {trough, }} \mu \mathrm{g} \mathrm{ml}^{-1}$ (from cycle 3)

\begin{tabular}{lcccc}
\hline $\begin{array}{l}\text { Dose } \\
\left(\mathbf{m g ~ k g} \mathbf{~ I}^{-\mathbf{I}}\right)\end{array}$ & $\begin{array}{c}\text { Number of } \\
\text { patients }\end{array}$ & $\begin{array}{c}\text { Free } \\
\text { aflibercept }\end{array}$ & $\begin{array}{c}\text { VEGF-bound } \\
\text { aflibercept }\end{array}$ & $\begin{array}{c}\text { Free/bound } \\
\text { ratio }\end{array}$ \\
\hline 4 & 6 & $4.19(84)$ & $3.80(26)$ & $1.08(83)$ \\
5 & 7 & $7.58(74)$ & $4.14(22)$ & $1.58(65)$ \\
6 & 15 & $4.94(107)$ & $3.71(28)$ & $1.30(108)$ \\
\hline
\end{tabular}

Abbreviations: $C_{\text {trough }}=$ concentration before dosing; $C V=$ coefficient of variation; $\mathrm{VEGF}=$ vascular endothelial growth factor.

Docetaxel CL (mean \pm standard deviation) was $24.3 \pm 7.091 \mathrm{~h}^{-1} \mathrm{~m}^{-2}$ and cisplatin $\mathrm{AUC}_{0-24}$ was $42.1 \pm 8.8 \mathrm{~h} \mu \mathrm{g} \mathrm{ml}^{-1}$. These values are consistent with data for docetaxel (Bruno et al, 1998; Harvey et $a l, 2006$ ) and cisplatin (sanofi-aventis internal data (data not shown)), indicating that aflibercept did not modify cisplatin and docetaxel PK.

\section{Immunogenicity}

All serum samples were negative for drug-specific anti-aflibercept antibodies for all patients.

\section{DISCUSSION}

This study determined the RP2D of aflibercept when given with the standard chemotherapy doublet of docetaxel and cisplatin. Some toxicities were higher than might be expected, however, in this heavily pretreated and heterogeneous population of patients with advanced solid tumours, it was demonstrated that the $\mathrm{AE}$ profile was manageable and consistent with that reported in other clinical studies with aflibercept (Leighl et al, 2010; Lockhart et al, 2010; Isambert et al, 2011), other anti-VEGF agents (Hurwitz et al, 2004; Sandler et al, 2006; Miles et al, 2010), and the combination of docetaxel and cisplatin (Fossella et al, 2003; Segawa et al, 2010; Chang et al, 2011). The incidence of the main DLT febrile neutropenia, expected with the cisplatin-docetaxel regimen (Aapro et al, 2011), was considerably reduced with the administration of prophylactic G-CSF. Adverse events associated with VEGF blockade, such as epistaxis, dysphonia and hypertension, were frequent, but manageable, and similar to those observed with other antiangiogenic drugs or with aflibercept (Isambert et al, 2011).

Five patients experienced PRs (16.7\%), four of whom received aflibercept $6 \mathrm{mg} \mathrm{kg}^{-1}$. The patients exhibiting PRs had different primary tumour sites (ovarian (two), breast, oesophagus, and pancreas) and three had taxane-refractory tumours. In addition, 18 patients $(60.0 \%)$ had SD, lasting $>3$ months in 10 patients. These results are consistent with the phase I study of aflibercept plus docetaxel in patients with advanced solid tumours (Isambert et al, 2011). In this study, 30 patients received aflibercept $6 \mathrm{mg} \mathrm{kg}^{-1}$ plus docetaxel, 4 experienced PRs (13.3\%), and 17 had SD (56.7\%), with 12 patients $(40.0 \%)$ experiencing stabilisation $>3$ months.

In the current study, the mean free to VEGF-bound aflibercept ratio was $>1$ over the $4-6 \mathrm{mg} \mathrm{kg}^{-1}$ dose range, suggesting there was sufficient free aflibercept to be biologically active. Adding aflibercept to docetaxel plus cisplatin did not influence the PK of the individual agents. On the basis of DLTs, an acceptable safety profile, PK, and evidence of durable antitumour activity, aflibercept $6 \mathrm{mg} \mathrm{kg}^{-1}$ with docetaxel $75 \mathrm{mg} \mathrm{m}^{-2}$ and cisplatin $75 \mathrm{mg} \mathrm{m}^{-2}$ every 3 weeks was selected as the RP2D.

Final results from phase III studies of aflibercept plus chemotherapy have been recently published (Van Cutsem et al, 2011). In the VELOUR study in the second-line treatment of metastatic colorectal cancer $(n=1266)$, aflibercept plus 5-fluorouracil, leucovorin, and irinotecan improved the primary endpoint of overall survival (HR, 0.817; $P=0.003$ ), PFS (HR, 0.76; $P=0.00007$ ), and overall response rate (Van Cutsem et al, 2011). In the VITAL study in the second-line treatment of NSCLC, aflibercept plus docetaxel did not meet its primary endpoint of improving overall survival compared with docetaxel plus placebo (HR, 1.01; 95\% CI, 0.87-1.17) but did improve PFS (HR, 0.82; 95\% CI, $0.72-0.94)$ and overall objective response rate $(23.3 \%$ and $8.9 \%$, respectively). Results for aflibercept plus other chemotherapy combinations are awaited from trials in several tumour types, including metastatic prostate cancer.

In conclusion, aflibercept $6 \mathrm{mg} \mathrm{kg}^{-1}$ is the recommended dose in combination with docetaxel $75 \mathrm{mg} \mathrm{m}^{-2}$ and cisplatin $75 \mathrm{mg} \mathrm{m}^{-2}$ every 3 weeks (with prophylactic G-CSF), and evidence of antitumour activity in patients with advanced solid malignancies has been described. Because of the type, frequency, and severity of some AEs, this combination is not easily manageable in heavily pretreated patients, but feasible regarding the individual benefit risk ratio. 


\section{ACKNOWLEDGEMENTS}

This study was supported by sanofi-aventis in collaboration with Regeneron Pharmaceuticals. The authors received editorial support in the preparation of this manuscript provided by Cancer Communications and Consultancy Ltd, funded by sanofi-aventis. We are fully responsible for the content and editorial decisions for this manuscript.

\section{REFERENCES}

Aapro MS, Bohlius J, Cameron DA, Dal Lago L, Donnelly JP, Kearney N, Lyman GH, Pettengell R, Tjan-Heijnen VC, Walewski J, Weber DC, Zielinski C (2011) 2010 Update of EORTC guidelines for the use of granulocyte-colony stimulating factor to reduce the incidence of chemotherapy-induced febrile neutropenia in adult patients with lymphoproliferative disorders and solid tumours. Eur J Cancer 47: 8-32

Bruno R, Hille D, Riva A, Vivier N, ten Bokkel Huinnink WW, van Oosterom AT, Kaye SB, Verweij J, Fossella FV, Valero V, Rigas JR, Seidman AD, Chevallier B, Fumoleau P, Burris HA, Ravdin PM, Sheiner LB (1998) Population pharmacokinetics/pharmacodynamics of docetaxel in phase II studies in patients with cancer. J Clin Oncol 16: 187-196

Byrne AT, Ross L, Holash J, Nakanishi M, Hu L, Hofmann JI, Yancopoulos GD, Jaffe RB (2003) Vascular endothelial growth factor-trap decreases tumor burden, inhibits ascites, and causes dramatic vascular remodeling in an ovarian cancer model. Clin Cancer Res 9: 5721-5728

Chang PM, Tzeng CH, Chen MH, Tsao CJ, Su WC, Hwang WS, Chang YF, Chang SY, Yang MH (2011) Triweekly reduced-dose docetaxel combined with cisplatin in recurrent/metastatic head and neck squamous cell carcinoma: a multicenter phase II study. Cancer Chemother Pharmacol 68(6): 1477-1484

Ferrara N (2002) Role of vascular endothelial growth factor in physiologic and pathologic angiogenesis: therapeutic implications. Semin Oncol 29: $10-14$

Fossella F, Pereira JR, von Pawel J, Pluzanska A, Gorbounova V, Kaukel E, Mattson KV, Ramlau R, Szczesna A, Fidias P, Millward M, Belani CP (2003) Randomized, multinational, phase III study of docetaxel plus platinum combinations versus vinorelbine plus cisplatin for advanced non-small-cell lung cancer: the TAX 326 study group. J Clin Oncol 21: 3016-3024

Fukasawa M, Korc M (2004) Vascular endothelial growth factor-trap suppresses tumorigenicity of multiple pancreatic cancer cell lines. Clin Cancer Res 10: 3327-3332

Harvey V, Mouridsen H, Semiglazov V, Jakobsen E, Voznyi E, Robinson BA, Groult V, Murawsky M, Cold S (2006) Phase III trial comparing three doses of docetaxel for second-line treatment of advanced breast cancer. J Clin Oncol 24: 4963-4970

Hicklin DJ, Ellis LM (2005) Role of the vascular endothelial growth factor pathway in tumor growth and angiogenesis. J Clin Oncol 23: 1011-1027

Holash J, Davis S, Papadopoulos N, Croll SD, Ho L, Russell M, Boland P, Leidich R, Hylton D, Burova E, Ioffe E, Huang T, Radziejewski C, Bailey K, Fandl JP, Daly T, Wiegand SJ, Yancopoulos GD, Rudge JS (2002) VEGF-Trap: a VEGF blocker with potent antitumor effects. Proc Natl Acad Sci USA 99: 11393-11398

Huang J, Frischer JS, Serur A, Kadenhe A, Yokoi A, McCrudden KW, New T, O'Toole K, Zabski S, Rudge JS, Holash J, Yancopoulos GD, Yamashiro DJ, Kandel JJ (2003) Regression of established tumors and metastases by potent vascular endothelial growth factor blockade. Proc Natl Acad Sci USA 100: 7785-7790

Hurwitz H, Fehrenbacher L, Novotny W, Cartwright T, Hainsworth J, Heim W, Berlin J, Baron A, Griffing S, Holmgren E, Ferrara N, Fyfe G, Rogers B, Ross R, Kabbinavar F (2004) Bevacizumab plus irinotecan, fluorouracil, and leucovorin for metastatic colorectal cancer. $N$ Engl J Med 350: 2335-2342

Isambert N, Freyer G, Zanetta S, You B, Fumoleau P, Falandry D, Favier L, Assadourian S, Soussan-Lazard K, Ziti-Ljajic S, Trillet-Lenoir V (2011) Phase I dose-escalation study of intravenous aflibercept in combination with docetaxel in patients with advanced solid tumors. Clin Cancer Res 18(6): 1743-1750

Lal D, Park JA, Demock K, Marinaro J, Perez AM, Lin MH, Tian L, Mashtare TJ, Murphy M, Prey J, Wetzler M, Fetterly GJ, Wang ES (2010)
Aflibercept exerts antivascular effects and enhances levels of anthracycline chemotherapy in vivo in human acute myeloid leukemia models. Mol Cancer Ther 9: 2737-2751

Lassoued W, Murphy D, Tsai J, Oueslati R, Thurston G, Lee WM (2011) Effect of VEGF and VEGF Trap on vascular endothelial cell signaling in tumors. Cancer Biol Ther 10: 1326-1333

Leighl NB, Raez LE, Besse B, Rosen PJ, Barlesi F, Massarelli E, Gabrail N, Hart LL, Albain KS, Berkowitz L, Melnyk O, Shepherd FA, Sternas L, Ackerman J, Shun Z, Miller VA, Herbst RS (2010) A multicenter, phase 2 study of vascular endothelial growth factor trap (Aflibercept) in platinum- and erlotinib-resistant adenocarcinoma of the lung. $J$ Thorac Oncol 5: 1054-1059

Leujeune P, Chiron M, Le Moigne R, Vrignaud P, Bissery M-C (2008) Combination of the antiangiogenic agent aflibercept (VEGF Trap) with docetaxel or gemcitabine results in greater antitumor activity in tumor bearing mice. Proc Am Assoc Can Res 12: (abstract 1107)

Lockhart AC, Rothenberg ML, Dupont J, Cooper W, Chevalier P, Sternas L, Buzenet G, Koehler E, Sosman JA, Schwartz LH, Gultekin DH, Koutcher JA, Donnelly EF, Andal R, Dancy I, Spriggs DR, Tew WP (2010) Phase I study of intravenous vascular endothelial growth factor trap, aflibercept, in patients with advanced solid tumors. J Clin Oncol 28: 207-214

Miles DW, Chan A, Dirix LY, Cortes J, Pivot X, Tomczak P, Delozier T, Sohn JH, Provencher L, Puglisi F, Harbeck N, Steger GG, Schneeweiss A, Wardley AM, Chlistalla A, Romieu G (2010) Phase III study of bevacizumab plus docetaxel compared with placebo plus docetaxel for the first-line treatment of human epidermal growth factor receptor 2-negative metastatic breast cancer. J Clin Oncol 28: 3239-3247

Regeneron Pharmaceuticals Inc. Press release. Sanofi-aventis and Regeneron report top-line results from the phase III study with aflibercept (VEGF Trap) in second-line non-small cell lung cancer. http://newsroom.regeneron.com/ releasedetail.cfm?ReleaseID $=556162$ (2011) (accessed June 2011)

Sandler A, Gray R, Perry MC, Brahmer J, Schiller JH, Dowlati A, Lilenbaum R, Johnson DH (2006) Paclitaxel-carboplatin alone or with bevacizumab for non-small-cell lung cancer. N Engl J Med 355: 2542-2550

Segawa Y, Kiura K, Takigawa N, Kamei H, Harita S, Hiraki S, Watanabe Y, Sugimoto K, Shibayama T, Yonei T, Ueoka H, Takemoto M, Kanazawa S, Takata I, Nogami N, Hotta K, Hiraki A, Tabata M, Matsuo K, Tanimoto M (2010) Phase III trial comparing docetaxel and cisplatin combination chemotherapy with mitomycin, vindesine, and cisplatin combination chemotherapy with concurrent thoracic radiotherapy in locally advanced non-small-cell lung cancer: OLCSG 0007. J Clin Oncol 28: 3299-3306

Therasse P, Arbuck SG, Eisenhauer EA, Wanders J, Kaplan RS, Rubinstein L, Verweij J, Van Glabbeke M, van Oosterom AT, Christian MC, Gwyther SG (2000) New guidelines to evaluate the response to treatment in solid tumors. European Organization for Research and Treatment of Cancer, National Cancer Institute of the United States, National Cancer Institute of Canada. J Natl Cancer Inst 92: 205-216

Van Cutsem E, Tabernero J, Lakomy R, Prausova J, Ruff P, Van Hazel G, Moiseyenko V, Ferry D, McKendrick J, Tellier A, Castan R, Allegra C (2011) Intravenous (IV) aflibercept versus placebo in combination with irinotecan/5-FU (FOLFIRI) for second-line treatment of metastatic colorectal cancer (MCRC): results of a multinational phase III trial (EFC 10262-VELOUR). Ann Oncol 22(Suppl 5): v18 (abstract $\mathrm{O}-0024)$

Verheul HM, Hammers H, van Erp K, Wei Y, Sanni T, Salumbides B, Qian DZ, Yancopoulos GD, Pili R (2007) Vascular endothelial growth factor trap blocks tumor growth, metastasis formation, and vascular leakage in an orthotopic murine renal cell cancer model. Clin Cancer Res 13: $4201-4208$

This work is published under the standard license to publish agreement. After 12 months the work will become freely available and the license terms will switch to a Creative Commons Attribution-NonCommercial-Share Alike 3.0 Unported License. 